\title{
レーザ溶接によるアルミニウム合金展伸材の強度特性
}

\section{Strength Properties of Aluminum Wrought Alloy by Laser Welding}

\author{
○学 鈴木 靖之（日大院）正柴田 文男（日大理工）
}

Yasuyuki SUZUKI, Graduate School of Nihon University, 7-24-1, Narashinodai, Funabashi-shi, Chiba, 274-8501 Fumio SHIBATA, Department of Precision Machinery Engineering, College of Science and Technology Nihon University

Key Words: Aluminum Wrought Alloy, Laser Welding, Tensile Test, Impact Test, Bending Test

\section{1. 䋨言}

アルミニウム合金展伸材（以下A1合金展伸材と記す）は， 軽量，熱伝導性，耐食性及び非磁性などに優れており，今 日自動車関係を始めとして，建築，船舶，日用品などに使 用されている。しかし，A1合金は比熱，溶融潜熱，熱伝導 度が高いため，大きな熱量を必要とし，局所加熱が困難で ある。そのため，A1合金溶接継手の強度が要求される組立 溶接に関して系統的に取り扱った報告は極めて少ない(1),2).

そこで本報告では，レーザ溶接によるA1合金展伸材の溶 接継手の硬さ，引張，衝撃及び曲げ特性などについて若干 検討した。

\section{2. 供試材料及び实歌方法}

供試材には，A1-Mg系合金展伸材 (A5052-H112)を使用し た. Table1に母材の化学成分と機械的性質を示守.また， 母材のミクロ組織をFig. 1に示す。母材の寸法は，t6× $100 \times 100 \mathrm{~mm}$ とした。使用した溶接装置は，定格出力 $5 \mathrm{~kW}$ $\mathrm{CO}_{2}$ レーザ溶接機である。Fig. 2に溶接時のシールドガス方 法を示す，溶接中の大気の侵入を防ぐために，シールドガ スを，(1)ノズル内，(2)シールドボックス内，(3)母材と治具 との間の 3 方向から供給した。溶接前処理として, 具材の 表面及び突合せ面の酸化皮膜をワイヤブラシで除去し，ア セトンで十分に洗浄した。溶接条件は，基䃈実験の結果か ら、レーザ出力 $5 \mathrm{~kW}$ ，溶接速度 $1000 \mathrm{~mm} / \mathrm{min}$, 焦点位置 $+1 \mathrm{~mm}$, シールドガス流量10〜50//min(Ar)で行った。この場合の 溶接入熱梳 $3000 \mathrm{~J} / \mathrm{cm}$ である。そして，Fig.3に示すごとく， 溶接前処理後, 母材両端を治具で軽く固定して，I 形突合 せ溶接を行った。目材及び溶接部の組織観察は，バフ研磨 後, $5 \%$ フッ化水素酸水溶液で腐食し, 光学䫓微鏡で観察し た。母材及び溶接継手材の材料試験として，マイクロビッ カース硬さ試験 (硬さ記号: HV0.3), 引張試験 (JIS 5 号), Vノッチシャルピー衛撃試験及び曲げ試験 (JIS Z 3122)を 実施した。

\section{3. 実嗝結果}

\section{1 溶接部の組鎞と硬さ}

溶接ビードの表面には，スパッタがわずかに認められた。 また，溶融凝固部にはポロシティが認められ，その直径は 最大で $750 \mu \mathrm{m}$ はどであった。これは，シールドガスに用い たArガスの巻き込みによるものと思われる，な扮，溶融凝 固部はデンドライト組織を呈し，その組織は母材に比べて 著しく微細化した。 Fig. 4に溶接部の硬さ分布を示す。溶 融凝固部の平均硬さは61HVで，溶接前の母材とほぼ同等の 値を示した。
Table1 Chemical compositions and mechanical properties of base metal.

\begin{tabular}{|c|c|c|c|c|c|c|c|c|c|}
\hline \multicolumn{6}{|c|}{ Chemical composition (mass\%) } & \multicolumn{2}{c|}{$\begin{array}{c}\text { Mechanical } \\
\text { properties }\end{array}$} \\
\hline $\mathrm{Cu}$ & $\mathrm{Si}$ & $\mathrm{Mg}$ & $\mathrm{Zn}$ & $\mathrm{Fe}$ & $\mathrm{Mn}$ & $\mathrm{Cr}$ & $\mathrm{A} 1$ & $\begin{array}{c}\text { T. S. S } \\
(\mathrm{MPa})\end{array}$ & $\begin{array}{c}\text { E1 } \\
(\%)\end{array}$ \\
\hline 0.03 & 0.10 & 2.50 & 0.03 & 0.22 & 0.06 & 0.21 & $\mathrm{Ba1}$ & 189 & 29 \\
\hline
\end{tabular}

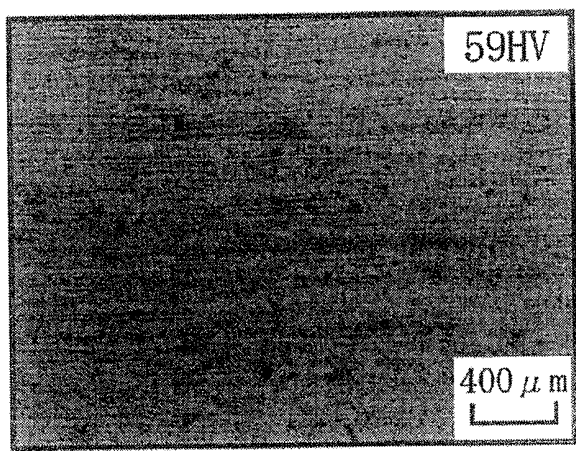

Fig. 1 Microstructure and vickers hardness of base metal.
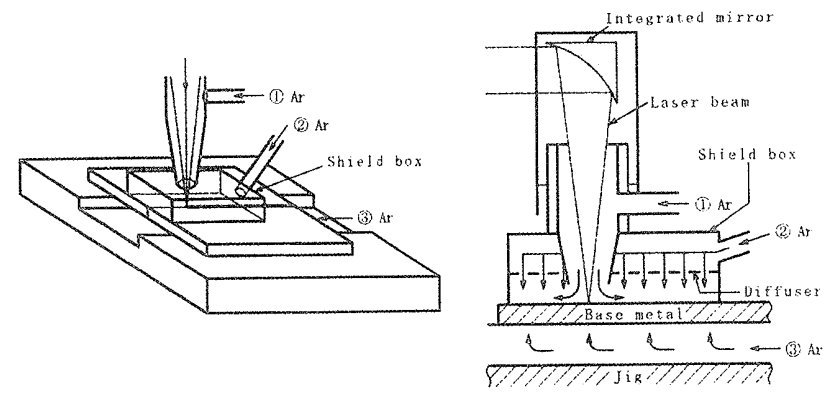

Fig. 2 Shielding gas method.

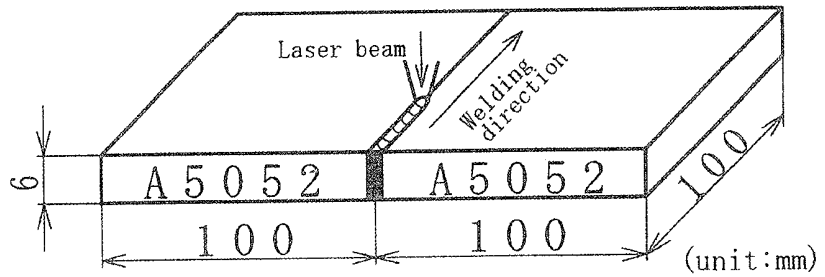

Fig. 3 Joint configuration. 


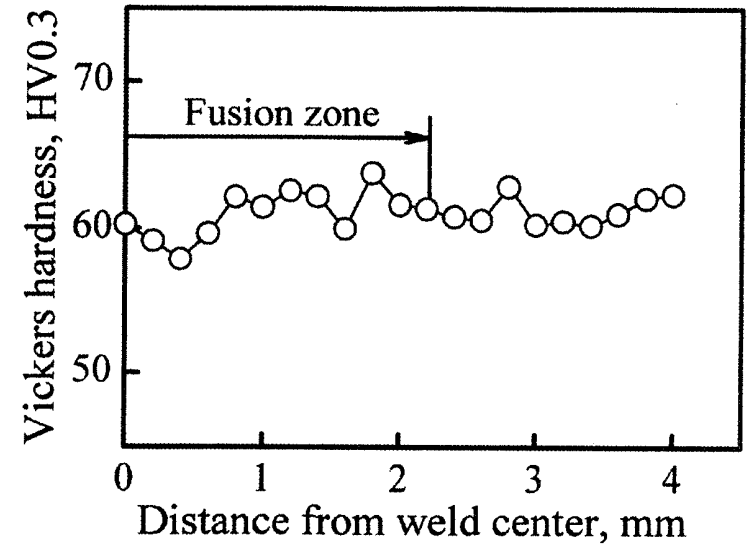

Fig. 4 Vickers hardness distribution of welds.

\section{2 溶接継手の引張特性}

Fig. 5に溶接継手の引張強さと伸びを示す．溶接継手の 引張強さは, 173〜200́Paを示し, 試験片 7 本の平均值は 190MPaであった。また，溶接継手の引張強さと母材強さの 比で与えられる継手効率は92〜100\%を示し，その平均值は 98\%ほどであった，一方，溶接継手の伸びは，9〜28\%を示 し，その平均値は $17 \%$ を示し，母材の $29 \%$ に比べて低かった。 なお，溶融凝固部に発生したポロシティの増大とともに引 張強さと伸びはほぼ直線的に低下する傾向を示した。

\section{3 溶接継手の衝撃特性}

Fig. 6 に母材及び溶接継手の衝撃值と試験温度 $(98 \mathrm{~K} \sim$ 473K) との関係を示す，母材の衝撃值は，各試験温度にお

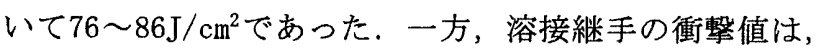
各試験温度において $27 \sim 48 \mathrm{~J} / \mathrm{cm}^{2}$ を示し，いずれの試験温 度においても母材に比べて著しく低かった。

\section{4 溶接継手の曲げ特性}

Fig. 7に溶接継手の曲げ試験後の外観を示す，溶接継手 の曲げ試験では，曲げ角度 $60 \sim 180^{\circ}$ の範囲で種々変化さ せて調べた，その結果，曲げ角度 $120^{\circ}$ の場合には溶融凝 固部内にポロシティが存在したため，ポロシティからき裂 が発生した。しかし，曲げ角度 $60^{\circ} ， 90^{\circ} ， 150^{\circ}, 180^{\circ}$ の 場合はき裂などは認められず，良好な曲げ特性を示した。

\section{4. 結言}

レーザ溶接によるA1合金展伸材溶接継手の強度について 二，三検討した結果を，下記に示す。

（1）溶融凝固部にポロシティが認められた.

（2）溶接継手の平均引張強さは190MPaを示した。また，

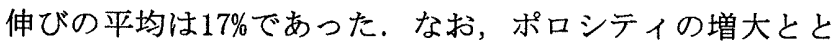
もに引張強さと伸びは低下した。

（3）溶接継手の衝撃值は，いずれの試験温度においても 母材より著しく低かった。

（4）溶接継手の曲げ試験では，曲げ角度 $180^{\circ}$ において 良好な性能を示した。

\section{参考文献}

1) 鈴木，柴田他：第52期日本材料学会学術講演会講演論 文集52(2003) 204

2) 柴田, 鈴木他: 第46回日本学術会議材料研究連合講演 会講演論文集46(2002) 61

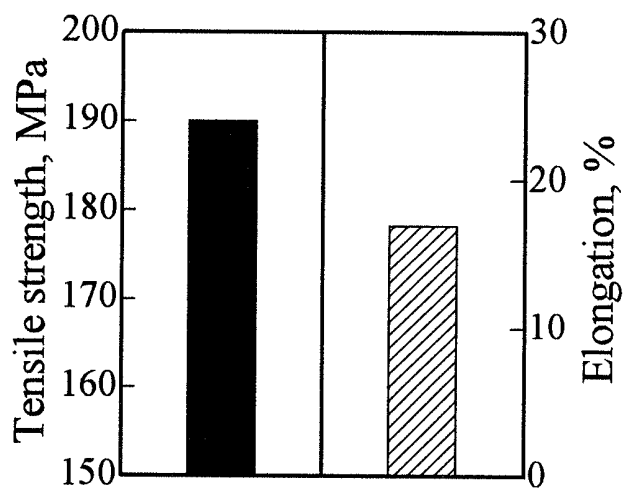

Fig. 5 Tensile strength and Elongation of welded joints.

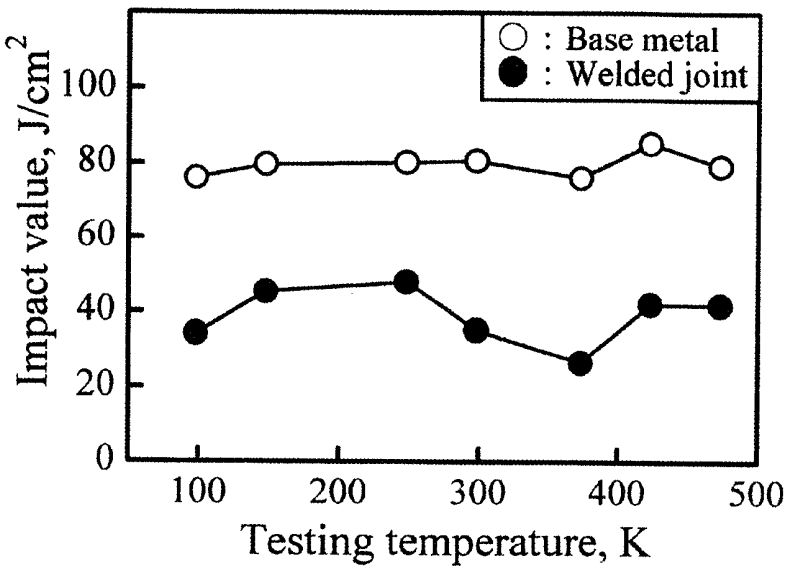

Fig. 6 Relation between impact value and testing temperature of base metal and welded joints.

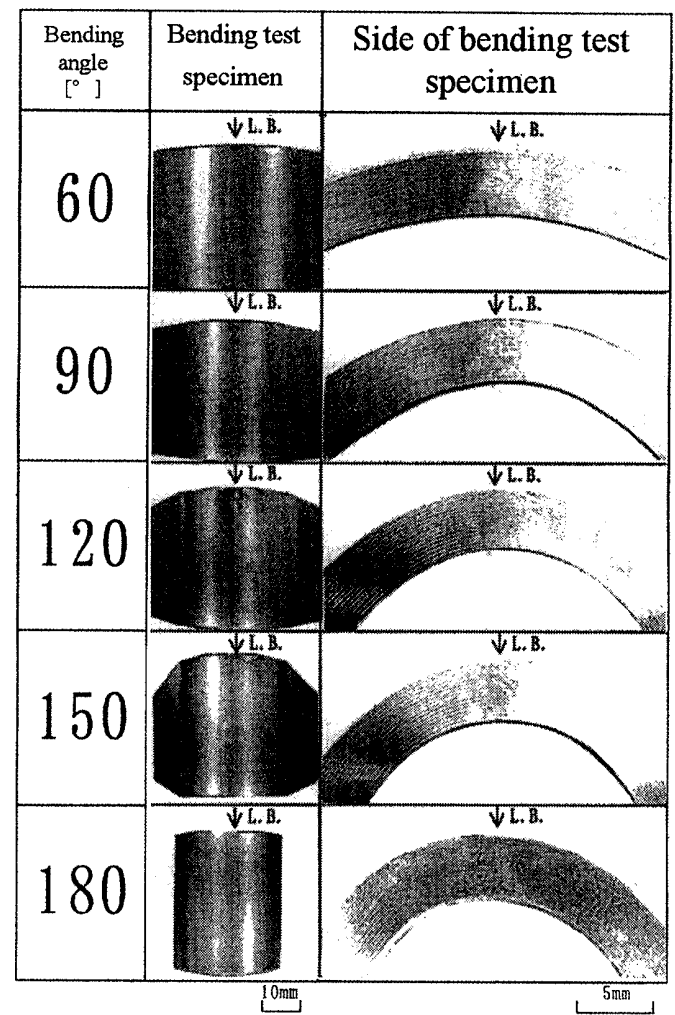

Fig. 7 Test specimen after bending test of welded joints. 